\title{
Strategies for re-orienting agricultural education towards hands on experience in Rivers State Universities
}

\author{
Amadi NS ${ }^{*}$ and Adejoh G \\ Department of Vocational and Technology Education Faculty of Education Rivers State University, Nigeria.
}

Publication history: Received on 26 November 2020; revised on 06 December 2020; accepted on 08 December 2020

Article DOI: https://doi.org/10.30574/gscarr.2020.5.3.0114

\begin{abstract}
The study examines the strategies for re-orienting agricultural education towards hands on experience in Rivers State Universities. The objectives of the study was to students' assessment, teaching strategies, and administrative strategies for re-orienting agricultural Education Towards hands on experience in Rivers State Universities. Three research questions and hypotheses were formulated. The design of the study employed was a descriptive survey research design. The population of the study was 18 agricultural education lecturers from Rivers State Universities. The sampling technique used was census sampling technique, therefore all the population was used for the study. The instrument used for the study was a self-designed questionnaire. The instrument was vetted for validity and reliability. Cronbach Alpha reliability formula was used to establish the reliability of the study which gave a 0.95 reliability coefficient. The method of data analysis used were mean and standard deviation while independent sample t-test was used to test hypothesis at 0.05 level of significance. Findings showed that assessing students' pedagogical knowledge, evaluating students' agricultural content mastery, appraising students based on their practical competence, consistent use of demonstration farms, use of assignment/project method for teaching practical, close supervision of students during practical exercises, encouraging the use of farm workshops, approving awards of certificate of excellence only when students are able to demonstrate professional competences in farming, provision of instructional materials for teacher among others. The study recommended that administrators should place much emphasis on the need for students to display absolute competency in agricultural production before award of degrees, this will enforce students to take their practical works very serious.
\end{abstract}

Keywords: Strategies; Re-orienting; Agricultural; Education; Hands-on; Experience

\section{Introduction}

Agricultural education is considered one of the major tools of developing human resources in agricultural skills or hand on expertise for self-reliance. Agricultural education programme essentially provide instructions for learners on crop production, livestock management, soil and water conservation and other aspects of agriculture (Nnodim and Amadi, 2018). Agricultural education is generally focused on producing seasoned skilled manpower that will shape and develop agricultural industries around the world. The aim of teaching agricultural education in tertiary institutions is to produce citizens with skills competencies and reasoned judgment to successfully live and add meaningfully to the economic growth of Nigeria (Amadi \& Lazarus, 2017). Based on the foregoing, it is obvious that the focus of agricultural education is geared towards hand-on experience.

Generally, Hands-on experience simply means learning by experience. This is a type of learning experience that enable students handle scientific instruments and manipulate the objects they are studying themselves (Rutherford in

\footnotetext{
* Corresponding author: Amadi NS

Department of Vocational and Technology Education Faculty of Education Rivers State University, Nigeria.
} 
Holstermann, Grube and Sussane, 2010). It is assumed that working in a hands-on way provides a more realistic and exciting experience of the content (Franklin and Peat, 2005; Holstermann, Grube \& Sussane, 2010). Various empirical studies provide evidence for the assumption that conducting hands-on activities leads to positive motivational outcomes develop interest, increase students' academic performance and retention. In the empirical studies of Holstermann, et al. (2010) it was found that hands-on activities significantly rises students' interest in academic activities. Hands-on experience is a learning experience where students are guided to gain knowledge by experience (Ekwueme, Ekon, \& Ezenwa-Nebife, 2015). It involves enabling the students to manipulate available materials or object that portrays the concepts of study. This approach gives students the opportunity to actually experience the theories posited on the blackboard as a reality. For instance in agricultural classes, when students are taught cultivation of field crops such as cassava, teacher create an enabling environment where actually cultivation can take place.

However, agricultural education programme has been saddled much impediment which had deviated its focused to ordinary teaching of theories (Amadi \& Lazarus, 2017). They identified lack of funding, teachers and students lack of interest in practical work, inadequate competent personnel and poor provision of essential facilities that could aid hands on experience. These thriving constraints that facilitate the inability to accomplish agricultural education aim is the exclusion of hands on experience. The objective of agricultural education in Nigeria institutions involves stimulation and sustenance of students' interest in Agriculture, impart functional knowledge and practical skills in agriculture, and prepare students for further studies and for agricultural occupations. Various empirical studies have observed that agricultural education in tertiary institutions has failed to produce graduates that possess adequate skills for sustainable agricultural production. Since they do not possess the required skills they tends to find it difficult to establish sustainable business in this line for self-reliance. This is the implication of lack of hand-on experience in teaching and learning.

This situation is not only dominant in agricultural education alone, as observed by Olatoye (2012) the educational structure and curriculum have not be tailored towards a reawakening of our youth for self-reliance as obtainable in in some countries. Mostly in agricultural education programme after students complete their academic training they are tested for their pedagogical knowledge and agricultural content mastery without much emphasis on the skill acquisition or hands on experience skill. Successful teaching includes the learner obtaining with minimal proficiency essential skill for competent agricultural display. Hands-on-approach has been proposed as a means to increase students' skill proficiency and understanding of concepts by manipulating objects which may make abstract knowledge more concrete and clearer (Ekwueme, Ekon, \& Ezenwa-Nebife, 2015). In order to re-orient agricultural education towards hands-on experience, there is need to examine the major tenets of that could enforce hands on experience and apply them to agricultural education programme.

The strategies adopted for students' assessment is a major principle that could be used to reengineer the present medium of delivering agricultural education programme. Assessment is carried out in any educational programme to determine whether learners have been able to acquire desirable learning outcome or not using two methods which are continuous assessment method and conventional and conventional method of assessment (Lamidi 2013). According to Lamidi, students are expected to have competent in all domains under each area. The cognitive domain is of six levels, in ascending order, they are knowledge, comprehension, application, analysis, synthesis and evaluation. Pupils in primary school levels are not supposed to cover more than the first two levels of cognitive domain (Okwilagwe, 2000). The affective domain has five levels namely receiving, responding, valuing, organization and characterization. They have to do with values, beliefs, attitudes and appreciation, interest, social relations, emotional adjustments, habits and life styles while the psychomotor domain deals with the way pupils manipulate objects and move their hands and bodies, these are observed in such activities as writing, drawing and setting-up of laboratory equipment. Jenkins, Kitchel \& Hains (2012) students' assessment in agricultural education involves measuring not only students' level of agricultural content and theory mastery, that is, the cognitive domain but also their skill competence level (Psychomotor). Since many institution place less emphasis on skill competence, the consequence is notable in the inability of most agricultural education graduates to secure jobs or self-employed and have the perceived generation gap which has been on the way and manner agricultural education programme in being implemented (Farauta \& Amunche, 2013). For proper and all round assessment learners of agricultural education should be assessed based on their ability to produce crops for consumption, rear or breed animals, ability to impart others with the knowledge of agriculture, ability to apply theories on real life practical. Kauffman and colleagues (1971) supported this, by stating that educational experience of agricultural students should include the cognitive domain, the affective domain (interest, attitudes, and values), and the psychomotor domain (manipulations requiring neuromuscular coordination). Students would be adjudged to be worthy of agricultural education certificate when he/she have displayed satisfactorily in all level of domains. The teacher must be systematic in his or her procedures, implying that the teacher is exposed to many of such procedures, leading to good and effective assessment. 
The goal of teaching methods in the field of agricultural science (because of its specificity) is that students memorize new course material, which is often necessary to be deepened by the additional curriculum content, and to apply theoretical knowledge in practice. The teaching process in agricultural education is quite complex, because it requires not only the acquisition of knowledge but the development of specific competencies and skills too, which in the end must also be taken into consideration when evaluating the general knowledge of students (Agricvoc, 2015). For teacher to be successful in imparting agricultural education students with all round knowledge in agriculture, he/she should employ a good teaching strategy that could help in this task. For instance Şahin, Kumar \& Altun (2016) posited that for teachers to be able to building up analytical thinking in new era students, other pedagogical approaches are needed to be applied such as living at the farm all the year, mentoring in the art of agriculture, giving students to see the seasonal changes in farm ecology, allowing them to drive tractor, use other agricultural equipment \& tools, practicing agriculture on soil, on plant, on animals and also in marketing and serving, hunting and handling animals, cleaning farm yards and gardens, making fence or paddocks, constructing agricultural buildings, harvesting or collecting agricultural products from plants, animals, and bee hives, re-using farm materials, practicing on farm accounting, processing foods and feeds, making cheese, classifying eggs, fleecing, hatching eggs in hatchery, feeding animals in shelter and pasture land, irrigating and fertilizing plants, levelling land, vaccinating of animals, implanting and pruning plants, and storage agricultural inputs, raw materials and end-products. The involving of these all activities will give students permanent effects in learning. When they read these related subjects in their textbooks, they do not need to memorize these agricultural contents, just living with these contents will be enough for them to master their agricultural knowledge and, consequently, understand what their teachers mention. Teaching methods need to be designed in a way that the responsible teacher has the possibility to analyze all aspects of the knowledge acquired by the student. This amount to the reason why Agricvoc (2015) recommended internship programme, real life demonstration of agirucultural theories in the farm, engagement of students in field trip work and close supervision of students when carrying out practical tasks. However, there is need for qualified/ certified agricultural instructor for effective delivery of agricultural education programme (Amadi and Solomon, 2019).

Darling-Hammond (2006), and Darling-Hammond and Bransford (2005), Barrick and Garton (2010) professed that subject matter knowledge alone is not sufficient for the effec-tive teaching of agriculture. Pre-service teachers are expected to acquire knowledge and skills related to teaching that allows their students to learn and understand the subject matter of agri-culture (Barrick \& Garton, 2010, Auwal, 2013). McCraken in Stripling and Barrick (2013) stated that Agricultural teachers are to be prepared as specialists in a technical agricultural content area with a general knowledge of agriculture versus being prepared as agricultural generalists because of the loss of commonality among the different agricultural technical content areas. He cited that the loss of commonality was due to the shift in agriculture from general crop and livestock farms to specialized farms and jobs within agricultural industries, thus reducing the breadth of technical competencies required of an agricultural workforce.

Strategies for re-orienting agricultural education cannot be effectively discussed leaving role of administrators behind. Administrators of agricultural education programme has a lot of role in ensuring that the programme is delivered to learners to its fullest capacity. The curriculum of agricultural education program consists of compulsory and elective courses, practical training and final thesis. It is therefore the responsibility of the administrators to ensure that the curriculum content and activities are delivered to learners efficiently. Besides, hands-on experience approach to learning agricultural education would require the provision of certain facilities such as demonstration farm, farm instructors, farm machineries, farm land among others (Agrivoc, 2015). Tertiary institution without these facilities are therefore incompetent to carry out the programme.

Likewise, planning and organizing field trips involves administrative supports, many times poor administration could make process of implementation complicated. It is very important that the question of the organization of field trips is not formalized, but perceived as a serious need to train young people. In doing so, it is expected that all parties participating in the implementation of agricultural education curriculum demonstrate their responsibility.

In this study, we explored agricultural education lecturers' perspectives on the strategies that could be implemented to redirect the present focus of agricultural education to hands-on experience.

\subsection{Purpose of the study}

The major purpose of the study is to determine the strategies for re-orienting agricultural Education Towards hands on experience in Rivers State Universities. In specific terms, the study sought to 
- Determine students' assessment strategies for re-orienting agricultural Education Towards hands on experience in Rivers State Universities

- Determine teaching strategies for re-orienting agricultural Education Towards hands on experience in Rivers State Universities

- Determine administrative strategies re-orienting agricultural Education Towards hands on experience in Rivers State Universities

\subsection{Research Questions}

The following research questions guided the study

- What are the students' assessment strategies for re-orienting agricultural Education Towards hands on experience in Rivers State Universities

- What are the teaching strategies for re-orienting agricultural Education Towards hands on experience in Rivers State Universities

- What are the administrative strategies re-orienting agricultural Education Towards hands on experience in Rivers State Universities

\subsection{Hypotheses}

- There is no significant difference in the mean responses of agricultural education lecturers in RSU and IAUE on students' assessment strategies for re-orienting agricultural Education Towards hands on experience in Rivers State Universities

- There is no significant difference in the mean responses of agricultural education lecturers in RSU and IAUE on teaching strategies for re-orienting agricultural Education Towards hands on experience in Rivers State Universities

- There is no significant difference in the mean responses of agricultural education lecturers in RSU and IAUE on administrative strategies re-orienting agricultural Education Towards hands on experience in Rivers State Universities

\section{Methodology}

The study was carried out in Rivers State. Rivers State is one of the thirty-six states of Nigeria, whose major income is affiliated to the crude oil found in many parts of the state. The study area has eight tertiary institutions and many agricultural activities are carried out within the study area. The design of the study employed was a descriptive survey research design. The population of the study was 18 agricultural education lecturers from Rivers State University (6) and Ignatius Ajuru University of Education (12). The both universities are the only universities in Rivers State that offer agricultural education programme. The sampling technique used was census sampling technique, therefore all the population was used for the study. That is all the population was engaged in the study. The instrument used for the study was a self-designed questionnaire titled Strategies for Re-orienting Agricultural Education towards Hands on Experience (SRAETHOE). The questionnaire was structured in a four point rating scale of Strongly Agree, Agree, Disagree and Strongly Disagree. The instrument was vetted for validity and reliability. Cronbach Alpha reliability formula was used to establish the reliability of the study which gave a 0.95 reliability coefficient. The instruments were distributed to agricultural education lecturers in the Rivers State University and Ignatius Ajuru University of Education. The method of data analysis used were mean and standard deviation while independent sample t-test was used to test hypothesis at 0.05 level of significance.

\section{Results and discussion}

Research Question 1: What are the students' assessment strategies for re-orienting agricultural education towards hands on experience in Rivers State Universities?

Table 1 presents students' assessment strategies for re-orienting agricultural education towards hands on experience in Rivers State Universities. The mean of each of the item showed that assessing students' pedagogical knowledge (3.06 \&3.55), evaluating students' agricultural content mastery (3.59 \& 3.42), appraising students based on their practical competence (3.08 \& 3.60), assessing students' leadership skills through future farmers association (3.76\& 3.54) evaluating students' communication skill through oral examination ( $3.45 \& 3.66$ ), appraising students' based on their ability to apply theories to practice in farm ( $3.68 \& 3.59)$, evaluating students' ability to impart agricultural knowledge to others ( $3.92 \& 3.86)$, assessing students' ability to produce and package crops for consumption(3.88 \& 3.60$)$,and 
evaluating students; ability to raise livestock for business (3.32 \&3.42) are students' assessment strategies for reorienting agricultural education towards hands on experience in Rivers State Universities.

Table 1 Students' assessment strategies for re-orienting agricultural education towards hands on experience in Rivers State Universities

\begin{tabular}{|l|l|l|l|l|l|l|l|}
\hline & & \multicolumn{2}{|l|}{ RSU Lecturers=6 } & \multicolumn{2}{l|}{ IAUE Lecturers=12 } \\
\hline S/N & Items & Mean & S.D & Remark & Mean & S.D & Remark \\
\hline 1 & $\begin{array}{l}\text { Assessing students' pedagogical } \\
\text { knowledge }\end{array}$ & 3.06 & 0.76 & Agreed & 3.55 & 0.69 & Agreed \\
\hline 2 & $\begin{array}{l}\text { Evaluating students' } \\
\text { agricultural content mastery }\end{array}$ & 3.59 & 0.68 & Agreed & 3.42 & 0.77 & Agreed \\
\hline 3 & $\begin{array}{l}\text { Appraising students based on } \\
\text { their practical competence }\end{array}$ & 3.08 & 0.54 & Agreed & 3.60 & 0.82 & Agreed \\
\hline 4 & $\begin{array}{l}\text { Assessing students' leadership } \\
\text { skills through future farmers } \\
\text { association }\end{array}$ & 3.76 & 0.72 & Agreed & 3.54 & 0.59 & Agreed \\
\hline 5 & $\begin{array}{l}\text { Evaluating students' } \\
\text { communication skill through } \\
\text { oral examination }\end{array}$ & 3.45 & 0.74 & Agreed & 3.66 & 0.62 & Agreed \\
\hline 6 & $\begin{array}{l}\text { Appraising students' based on } \\
\text { their ability to apply theories to } \\
\text { practice in farm }\end{array}$ & 3.68 & 0.63 & Agreed & 3.59 & 0.59 & Agreed \\
\hline 7 & $\begin{array}{l}\text { Evaluating students' ability to } \\
\text { impart agricultural knowledge } \\
\text { to others }\end{array}$ & 3.92 & 0.26 & Agreed & 3.86 & 0.53 & Agreed \\
\hline 8 & $\begin{array}{l}\text { Assessing students' ability to } \\
\text { produce and package crops for } \\
\text { consumption }\end{array}$ & 3.88 & 0.43 & Agreed & 3.60 & 0.64 & Agreed \\
\hline 9 & $\begin{array}{l}\text { Evaluating students; ability to } \\
\text { raise livestock for business. }\end{array}$ & 3.32 & 0.51 & Agreed & 3.42 & 0.57 & Agreed \\
\hline & Grand Mean\& S.D & 3.53 & 0.59 & & 3.58 & 0.65 & \\
\hline
\end{tabular}

Research Question 2: What are the teaching strategies for re-orienting agricultural Education Towards hands on experience in Rivers State Universities?

Table 2 teaching strategies for re-orienting agricultural Education Towards hands on experience in Rivers State Universities. According to the criterion mean value, the result revealed that lecturers agreed that use of instructional materials in every lesson (3.32 \& 3.52), gearing students' motivation towards agricultural business rather than jobs (3.56\& 3.65), teaching with the aim of imparting agricultural skills and not theories(3.79 \& 3.83), consistent use of demonstration farms(3.70 \& 3.83), use of assignment/project method for teaching practical(3.20 \&3.49), close supervision of students during practical exercises(3.59 \& 3.52), encouraging the use of farm workshops (3.56 \& 3.68), demonstrating the effectiveness of agricultural theories in the farm (3.86 \& 3.81), engaging students in field trips to integrated farms(3.64 \& 3.62), use of video clips of agricultural activities for teaching (3.48 \& 3.80) are teaching strategies for re-orienting agricultural education towards hands on experience in Rivers State Universities 
Table 2 Teaching strategies for re-orienting agricultural Education Towards hands on experience in Rivers State Universities.

\begin{tabular}{|c|c|c|c|c|c|c|c|}
\hline \multirow[b]{2}{*}{$\mathrm{S} / \mathrm{N}$} & \multirow[b]{2}{*}{ Items } & \multicolumn{3}{|c|}{ RSU Lecturers $=6$} & \multicolumn{3}{|c|}{ IAUE Lecturers=12 } \\
\hline & & Mean & S.D & Remark & Mean & S.D & Remark \\
\hline 1 & $\begin{array}{l}\text { Use of instructional materials in } \\
\text { every lesson }\end{array}$ & 3.32 & 0.76 & Agreed & 3.52 & 0.61 & Agreed \\
\hline 2 & $\begin{array}{l}\text { Gearing students' Motivation } \\
\text { towards agricultural business } \\
\text { rather than jobs }\end{array}$ & 3.56 & 0.63 & Agreed & 3.65 & 0.50 & Agreed \\
\hline 3 & $\begin{array}{l}\text { Teaching with the aim of } \\
\text { imparting agricultural skills and } \\
\text { not theories }\end{array}$ & 3.79 & 0.70 & Agreed & 3.83 & 0.40 & Agreed \\
\hline 4 & $\begin{array}{l}\text { Consistent use of demonstration } \\
\text { farms }\end{array}$ & 3.70 & 0.51 & Agreed & 3.83 & 0.39 & Agreed \\
\hline 5 & $\begin{array}{l}\text { Use of assignment/project } \\
\text { method for teaching practical }\end{array}$ & 3.20 & 0.62 & Agreed & 3.49 & 0.53 & Agreed \\
\hline 6 & $\begin{array}{l}\text { Close supervision of students } \\
\text { during practical exercises }\end{array}$ & 3.59 & 0.49 & Agreed & 3.52 & 0.74 & Agreed \\
\hline 7 & $\begin{array}{l}\text { Encouraging the use of farm } \\
\text { workshops }\end{array}$ & 3.56 & 0.59 & Agreed & 3.68 & 0.63 & Agreed \\
\hline 8 & $\begin{array}{l}\text { Demonstrating the effectiveness } \\
\text { of agricultural theories in the } \\
\text { farm }\end{array}$ & 3.86 & 0.62 & Agreed & 3.81 & 0.53 & Agreed \\
\hline 9 & $\begin{array}{l}\text { Engaging students in field trips } \\
\text { to integrated farms }\end{array}$ & 3.64 & 0.61 & Agreed & 3.62 & 0.65 & Agreed \\
\hline \multirow[t]{2}{*}{10} & $\begin{array}{l}\text { Use of video clips of agricultural } \\
\text { activities for teaching }\end{array}$ & 3.48 & 0.74 & Agreed & 3.80 & 0.45 & Agreed \\
\hline & Grand Mean\& S.D & 3.57 & 0.62 & & 3.67 & 0.54 & \\
\hline
\end{tabular}

Research Question 3: What are the administrative strategies for re-orienting agricultural Education Towards hands on experience in Rivers State Universities?

Table 3 presents administrative strategies for re-orienting agricultural Education Towards hands on experience in Rivers State Universities. Based on the criterion mean value, lecturers agree that approving awards of certificate of excellence only when students are able to demonstrate professional competences in farming (3.40 \& 3.63), provision of instructional materials for teacher (3.69 \& 3.42), facilitating teachers' plan for field trips (3.83 \& 3.64), provision of demonstration farms for students' practical (3.90 \& 3.55), approving the operation of young farmers club (3.55 \& 3.43 ), providing competent instructors in farm workshops (3.60 \&3.61), supervising teachers' quality instruction (3.73 \& 3.60), providing support for school farm organization and production (3.46 \& 3.53), mandating students' possession of farm area in the school farm before the award of degree (3.69 \& 3.89), consistent review of agricultural education curriculum (3.52 \& 3.63) and allocation of farm land for students' demonstration (3.32 \& 3.66) are possible administrative strategies for re-orienting agricultural Education Towards hands on experience in Rivers State Universities. 
Table 3 Administrative strategies for re-orienting agricultural Education Towards hands on experience in Rivers State Universities.

\begin{tabular}{|c|c|c|c|c|c|c|c|}
\hline \multirow[b]{2}{*}{$\mathrm{S} / \mathrm{N}$} & \multirow[b]{2}{*}{ Items } & \multicolumn{3}{|c|}{ RSU Lecturers $=6$} & \multicolumn{3}{|c|}{ IAUE Lecturers=12 } \\
\hline & & Mean & S.D & Remark & Mean & S.D & Remark \\
\hline 1 & $\begin{array}{l}\text { Approving awards of certificate of } \\
\text { excellence only when students are able to } \\
\text { demonstrate professional competences in } \\
\text { farming }\end{array}$ & 3.40 & 0.86 & Agreed & 3.63 & 0.63 & Agreed \\
\hline 2 & $\begin{array}{l}\text { Provision of instructional materials for } \\
\text { teacher }\end{array}$ & 3.69 & 0.55 & Agreed & 3.42 & 0.86 & Agreed \\
\hline 3 & Facilitating teachers' plan for field trips & 3.83 & 0.53 & Agreed & 3.64 & 0.45 & Agreed \\
\hline 4 & $\begin{array}{l}\text { Provision of demonstration farms for } \\
\text { students' practical }\end{array}$ & 3.90 & 0.34 & Agreed & 3.55 & 0.74 & Agreed \\
\hline 5 & $\begin{array}{l}\text { Approving the operation of young farmers } \\
\text { club }\end{array}$ & 3.55 & 0.56 & Agreed & 3.43 & 0.62 & Agreed \\
\hline 6 & $\begin{array}{l}\text { Providing competent instructors in farm } \\
\text { workshops }\end{array}$ & 3.60 & 0.61 & Agreed & 3.61 & 0.53 & Agreed \\
\hline 7 & Supervising teachers' quality instruction & 3.73 & 0.34 & Agreed & 3.60 & 0.69 & Agreed \\
\hline 8 & $\begin{array}{l}\text { Providing support for school farm } \\
\text { organization and production }\end{array}$ & 3.46 & 0.69 & Agreed & 3.53 & 0.73 & Agreed \\
\hline 9 & $\begin{array}{l}\text { Mandating students' possession of farm } \\
\text { area in the school farm before the award } \\
\text { of degree }\end{array}$ & 3.69 & 0.52 & Agreed & 3.89 & 0.52 & Agreed \\
\hline 10 & $\begin{array}{l}\text { Consistent review of agricultural } \\
\text { education curriculum }\end{array}$ & 3.52 & 0.51 & Agreed & 3.63 & 0.49 & Agreed \\
\hline \multirow[t]{2}{*}{11} & $\begin{array}{l}\text { Allocation of farm land for students' } \\
\text { demonstration }\end{array}$ & 3.32 & 0.71 & Agreed & 3.66 & 0.37 & Agreed \\
\hline & Grand Mean\& S.D & 3.61 & 0.57 & & 3.60 & 0.60 & \\
\hline
\end{tabular}

\subsection{Hypotheses}

$\mathrm{H}_{01}$ : There is no significant difference in the mean responses of agricultural education lecturers in RSU and IAUE on students' assessment strategies for re-orienting agricultural Education Towards hands on experience in Rivers State Universities

Table 4 t-test on the mean responses of agricultural education lecturers in RSU and IAUE on students' assessment strategies for re-orienting agricultural Education Towards hands on experience in Rivers State Universities.

\begin{tabular}{|c|c|c|c|c|c|c|c|c|}
\hline Groups & $\mathbf{N}$ & Mean & S.D & Lev. of sig & Df & t-cal & p-value & Remark \\
\hline \multirow{2}{*}{$\begin{array}{l}\text { RSU } \\
\text { lecturers }\end{array}$} & 6 & 3.53 & 0.59 & & & & & \\
\hline & & & & 0.05 & 16 & 0.16 & $\begin{array}{l}0.876 \\
P>0.05\end{array}$ & Fail to reject \\
\hline $\begin{array}{l}\text { IAUE } \\
\text { lecturers }\end{array}$ & 12 & 3.58 & 0.65 & & & & & \\
\hline
\end{tabular}


Table 4 shows the t-test analysis on the mean responses of agricultural education lecturers in RSU and IAUE on students' assessment strategies for re-orienting agricultural Education Towards hands on experience in Rivers State Universities. Analysis revealed that the p-value (0.876) is greater than the level of significance (0.05). Therefore the hypothesis failed to reject. That is, there is no significant difference in the mean responses of agricultural education lecturers in RSU and IAUE on students' assessment strategies for re-orienting agricultural Education Towards hands on experience in Rivers State Universities.

$\mathrm{H}_{02}$ : There is no significant difference in the mean responses of agricultural education lecturers in RSU and IAUE on teaching strategies for re-orienting agricultural Education Towards hands on experience in Rivers State Universities

Table 5 t-test on the mean responses of agricultural education lecturers in RSU and IAUE on teaching strategies for reorienting agricultural Education Towards hands on experience in Rivers State Universities.

\begin{tabular}{|l|l|l|l|l|l|l|l|l|}
\hline Groups & N & Mean & S.D & Lev. of sig & Df & t-cal & p-value & Remark \\
\hline $\begin{array}{l}\text { RSU } \\
\text { lecturers }\end{array}$ & 6 & 3.57 & 0.62 & & & & & \\
\hline & & & & 0.05 & 16 & 0.39 & $\begin{array}{l}0.703 \\
\text { P>0.05 }\end{array}$ & Fail to reject \\
\hline $\begin{array}{l}\text { IAUE } \\
\text { lecturers }\end{array}$ & 12 & 3.68 & 0.54 & & & & & \\
\hline
\end{tabular}

Table 5 presents the t-test analysis on the mean responses of agricultural education lecturers in RSU and IAUE on teaching strategies for re-orienting agricultural Education Towards hands on experience in Rivers State Universities. The result revealed that the p-value (0.703) is greater than the level of significance (0.05). Hence the null hypothesis failed to reject. This implies that there is no significant difference in the mean responses of agricultural education lecturers in RSU and IAUE on teaching strategies for re-orienting agricultural Education Towards hands on experience in Rivers State Universities.

H03: There is no significant difference in the mean responses of agricultural education lecturers in RSU and IAUE on administrative strategies re-orienting agricultural Education Towards hands on experience in Rivers State Universities

Table 6 t-test on the mean responses of agricultural education lecturers in RSU and IAUE on administrative strategies for re-orienting agricultural education towards hands on experience in Rivers State Universities.

\begin{tabular}{|l|l|l|l|l|l|l|l|l|}
\hline Groups & $\mathbf{N}$ & Mean & S.D & Lev. of sig & Df & t-cal & p-value & Remark \\
\hline $\begin{array}{l}\text { RSU } \\
\text { lecturers }\end{array}$ & 6 & 3.61 & 0.57 & & & & & \\
\hline & & & & 0.05 & 16 & 0.034 & $\begin{array}{l}0.973 \\
\text { P>0.05 }\end{array}$ & $\begin{array}{l}\text { Fail to } \\
\text { reject }\end{array}$ \\
\hline $\begin{array}{l}\text { IAUE } \\
\text { lecturers }\end{array}$ & 12 & 3.60 & 0.60 & & & & & \\
\hline
\end{tabular}

Table 6 presents t-test analysis on the mean responses of agricultural education lecturers in RSU and IAUE on administrative strategies re-orienting agricultural Education Towards hands on experience in Rivers State Universities. The result revealed that the p-value (0.973) is greater than the level of significance (0.05). Hence the null hypothesis failed to reject. This implies that there is no significant difference in the mean responses of agricultural education lecturers in RSU and IAUE on administrative strategies for re-orienting agricultural Education Towards hands on experience in Rivers State Universities.

\section{Discussion}

Findings from research question one shows that assessing students' pedagogical knowledge, evaluating students' agricultural content mastery, appraising students based on their practical competence, assessing students' leadership 
skills through future farmers association evaluating students' communication skill through oral examination, appraising students' based on their ability to apply theories to practice in farm, evaluating students' ability to impart agricultural knowledge to others among others are students' assessment strategies for re-orienting agricultural education towards hands on experience in Rivers State Universities. The findings is in cooperation with Jenkins, Kitchel \& Hains (2012) who posited that students' assessment in agricultural education involves measuring not only students' level of agricultural content and theory mastery, that is, the cognitive domain but also their skill competence level (Psychomotor). Kauffman and colleagues (1971) supported this, by stating that educational experience of agricultural students should include the cognitive domain, the affective domain (interest, attitudes, and values), and the psychomotor domain (manipulations requiring neuromuscular coordination).

Secondly the study found that use of instructional materials in every lesson, gearing students' motivation towards agricultural business rather than jobs, teaching with the aim of imparting agricultural skills and not theories, consistent use of demonstration farms, use of assignment/project method for teaching practical, close supervision of students during practical exercises, encouraging the use of farm workshops, demonstrating the effectiveness of agricultural theories in the farm, engaging students in field trips to integrated farms, use of video clips of agricultural activities for teaching are teaching strategies for re-orienting agricultural education towards hands on experience in Rivers State Universities. This finding is in line with the assertion of Agricvoc (2015) who recommended internship programme, real life demonstration of agricultural theories in the farm, engagement of students in field trip work and close supervision of students when carrying out practical task as effective teaching method that gears towards hand-on experience. Şahin, Kumar \& Altun (2016) posited that for teachers to be able to building up analytical thinking in new era students, other pedagogical approaches are needed to be applied such as mentoring in the art of agriculture, giving students to see the seasonal changes in farm ecology and farm project method among others.

Lastly, the study found that that approving awards of certificate of excellence only when students are able to demonstrate professional competences in farming, provision of instructional materials for teacher, facilitating teachers' plan for field trips, provision of demonstration farms for students' practical, approving the operation of young farmers club, providing competent instructors in farm workshops, supervising teachers' quality instruction, providing support for school farm organization and production, mandating students' possession of farm area in the school farm before the award of degree, consistent review of agricultural education curriculum and allocation of farm land for students' demonstration are possible administrative strategies for re-orienting agricultural Education Towards hands on experience in Rivers State Universities. This finding is in alliance with Agricvoc (2015) who posited that for administrators to promote hands-on experience approach to learning agricultural education there is need for the provision of certain facilities such as demonstration farm, farm instructors, farm machineries, farm land among others.

\section{Conclusion}

The study was carried to find out the strategies to re-orient agricultural education programme for hands on experience. The study concluded that students' assessment methods, teaching methods and mode of administration are the categories whereby orientation could take place gearing toward hands on approach to learning. The study further concluded that critical assessment of students' level of skill competence, engaging students in farm demonstration task among others are strategies to re-orient agricultural education for hands-on experience..

\section{Recommendations}

Based on the findings of this study it was recommended that

- Government should make fund available for institutes, colleges, and various department of agricultural education so as to enhance the availability of necessary facilities for effective delivery of agricultural education programme

- Agricultural education teachers should make use of teaching strategies that encourages hands-on experience such as demonstration, field trip, project method so as to impart needed skills in to learners for agricultural production

- Administrators should place much emphasis on the need for students to display absolute competency in agricultural production before award of degrees, this will enforce students to take their practical works very serious.

- Due to the fact agricultural education is a vocational course there students should be assessed more on the psychomotor abilities of the students and less of cognitive and affective as contrary to the present medium of assessment. 


\section{Compliance with ethical standards}

\section{Disclosure of conflict of interest}

No conflict of interest is exist.

\section{Statement of informed consent}

Informed consent was obtained from all individual participants included in the study.

\section{References}

[1] AgriVoc. Handbook on Teaching Methods in Agricultural Studies. The experience of higher education institutions from Serbia and Bosnia and Herzegovina. Laktasi, Grafomark. 2015.

[2] Amadi NS, Solomon UE. Assessment of Quality Instruction Indicators in Vocational Agricultural Education in South -South Universities Nigeria. IOSR Journal of Research \& Method in Education (IOSR-JRME). 2020; 10(3): 30-35.

[3] Nnodim AU, Amadi NS. Role of Agricultural Education Skills in Entrepreneurship Development in Rivers State. International Journal of Innovative Social \& Science Education Research. 2018; 6(1): 9-18.

[4] Auwal A. Effects of teaching method on retention of Agricultural Science knowledge in senior secondary schools of Bauchi Local Government Area, Nigeria. International Journal Science Technology Education Resources.2013; 4(4): 63-69.

[5] Barrick RK, Garton BL. Frameworks for agricultural teacher preparation. In R. M. Torres, T. Kitchel, \& A. L. Ball (Eds.), Preparing and advancing teachers in agricultural education. Columbus, $\mathrm{OH}$ : Curriculum Materials Service, The Ohio State University. 2010; 30-41.

[6] Crunkilton JR, Hemp PE. The curriculum: Professional education. In A. L. Berkey (ed.). Teacher education in agriculture. Danville, IL: Interstate Printers \& Publishers. 1982; 135-160.

[7] Darling-Hammond L. Powerful teacher education: Lessons from exemplary programs. San Fran-cisco, CA: JosseyBass.2006.

[8] Darling-Hammond L, Bransford J. Preparing teachers for a changing world. San Francisco, CA: Jossey-Bass. 2005.

[9] Ekeyi DN. Effect of demonstration method of teaching on students' achievement in agricultural science. World Journal of Education. 2013; 3(6): 1-7.

[10] Franklin S, Peat M. Virtual versus real: an argument for maintaining diversity in the learning environment. International Journal of Continuing Engineering Education and Life Long Learning. 2005; 15: 67-78.

[11] Holstermann N, Grube D, Sussane B. Hands-on Activities and Their Influence on Students' Interest. Research in science education. 2010; 40 (5): 743-757.

[12] Jenkins CC, Kitchel T, Hains B. Defining agricultural education instructional quality. Journal of Agricultural Education. 2012; 3(51): 53 - 63.

[13] Şahin A, Kumar A, Altun B. There is a need for pedagogical approach to agricultural education. 2016.

[14] Stripling CT, Barrick C. Examining the Professional, Technical, and General Knowledge Competencies Needed by Beginning School-Based Agricultural Education Teachers. Journal of Agricultural education. 2013 ; 54 (3): $67-83$. 